\title{
Field Evaluation of Resistance to White Pine Blister Rust of Selected Blackcurrant Genotypes in Poland
}

Stanislaw Pluta1 and Agata Broniarek-N iemiec ${ }^{2}$

Additional INDEX wORds. black currant, Cronartium ribicola, R ibesnigrum, resistance, breeding

Summary. Field resistance to white pine blister rust (WPBR) (C ronartium ribicola J. C. Fischer) was investigated on 53 black currant ( $R$ i besnigrum L.) genotypes (cultivars and breeding selections) in 1998 and $1999 . U$ redia did not form on the black currant 'T itania' and 17 advanced selections during field evaluations made at the Experimental Orchard at D abrowice, near Skierniewice, Poland.

or many years, Poland has been the top world producer of $\mathrm{R}$ ibesfruit. Black currants are one of the main horticultural crops produced in Poland. Annual fruit production of this crop ranges between 100 and 130 thousand tonnes (110.2 - 143.3 thousand tons) harvested from about 30,000 ha (74,000 acres). Polish $\mathrm{R}$ ibes acreage has increased over the last 2 years because of the high demand for fruit and high prices returned to Polish growers.

The major black currant cultivars in commercial production are 'O jebyn', 'T itania' and 'Ben Lomond'. Although excellent in many ways, these cultivars have some defects, including excessive vegetative growth ('Titania'), poor processing quality of fruits ('O jebyn', 'T itania') or susceptibility to fungal diseases ('O jebyn', 'Ben Lomond') (Broniarek et al., 1997, 1999). White pine blister rust (WPBR) is a severe disease affecting $R$ ibes This disease together with leaf spot (D repanopeziza ribisK elb.) causes complete defoliation of bushes. In Poland heavy infection can results in decreased ability survive low winter temperatures and in reduced yield for the subsequent year. Besides harming the R ibescrop, WPBR can damage forest trees (alternative host).

To resolve these difficulties, a new and expanded blackcurrant breeding program was implemented in 1986 at the Research Institute of Pomology and Floriculture at Skierniewice, Poland (Pluta and Zurawicz, 1993). The development of WPBR resistance or immunity in $\mathrm{R}$ ibesis one of the main goals of this breeding program. D onors of a resistance gene $\mathrm{Cr}$ are used as parents.

These are the $C$ anadian cultivars Consort, C rusader and Coronet, as well as the cultivar T itania (O golcova, 1991; Pluta and $\mathrm{H}$ ummer, 1996). O ther resistant parents, such as 'Belaruskaya Sladkaya' a selections of R . nigrum var. s bi ricum, are also being used.

The main objective of this study was to determine the WPBR field resistance of selected cultivars and breeding selections that were planted in 1994, 1995 and 1997.

The cost of publishing this paper was defrayed in part by the payment of page charges. U nder postal regulations, this paper therefore must be hereby marked advertisement solely to indicate this fact.

${ }^{1}$ Fruit Plant Breeding Department, Research Institute of Pomology and Floriculture, 96-100 Skierniewice, Pomologiczna 18, Poland.

2Plant Protection D epartment, Research I nstitute of Pomology and Floriculture, 96-100 Skierniewice, Pomologiczna 18 , Poland. 

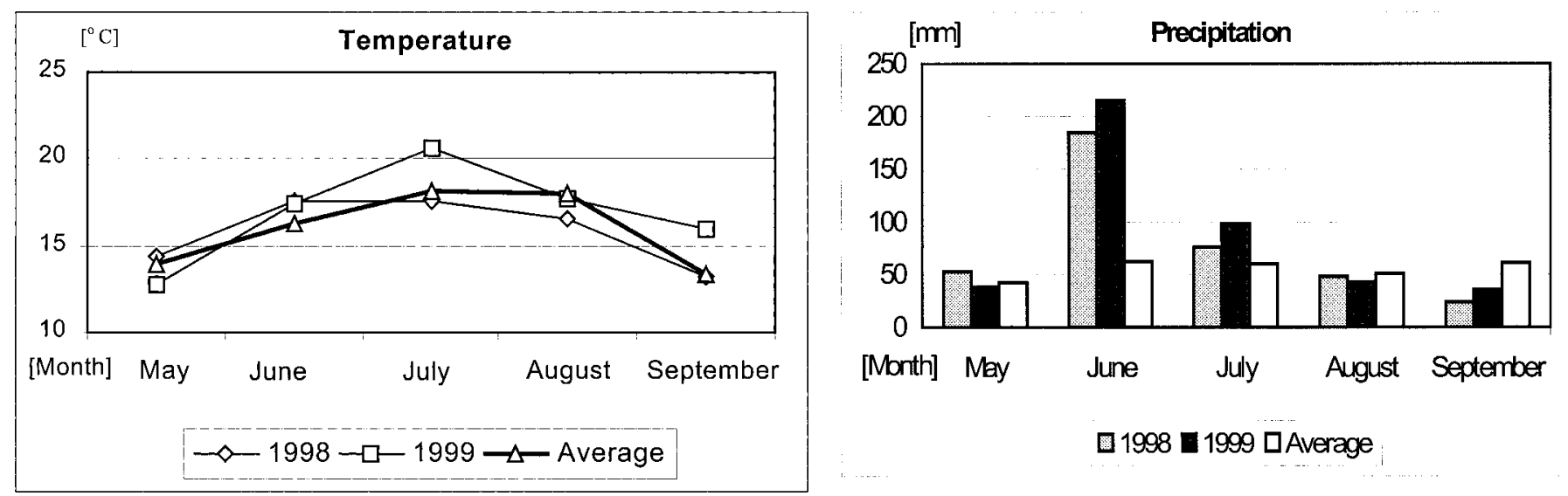

Fig.1. The monthly average temperature (A) and precipitation (B) recorded in central Poland in 1998 and $1998\left({ }^{\circ} \mathrm{F}=1.8\right.$ ${ }^{\circ} \mathrm{C}+32 ; 25.4 \mathrm{~mm}=1.0 \mathrm{inch}$ ).

\section{Materials and methods}

Black currant cultivars and advanced breeding selections were grown in two cultivar trialsplanted in 1994 and in 1995. In addition, over 20 selections (marked PC) originated from our breeding program, and planted at the clone collection in 1997, were also investigated. Field experiments were carried out at the Experimental Orchard at D abrowice, near Skierniewice (central Poland).

Cultivar trails were established in a random block design, in triplicate, with three plants per plot. Advanced selections were planted without replications, with three plants per individual plot. The genotypes were subjected to natural infection with WPBR under field conditions. N o chemical diseaseprotection was applied.

Genotypes were observed for the presence of WPBR urediain the middle of August and September in 1998 and 1999, using the ranking scale 1 to 5 ( 1 $=$ no symptoms, 5 = very severe symptoms on leaves). Plants were scored individually, with resultscollected from nine plants grown in the cultivar trials

T able 1. White pine blister rust (WPBR) field resistance of black currant genotypes planted in two cultivar trials in 1994 and 1995, at the Experimental Orchard, Dabrowice, Poland. M eans followed by the same letter within column do not differ significantly according to Duncan's multiple range test $(P=0.05)$.

\begin{tabular}{|c|c|c|c|c|}
\hline \multirow{2}{*}{$\begin{array}{l}\text { Cultivar } \\
\text { or selection }\end{array}$} & \multirow[b]{2}{*}{ Parentage } & \multicolumn{3}{|c|}{ WPBR rating ${ }^{2}$} \\
\hline & & 1998 & 1999 & Avg \\
\hline \multicolumn{5}{|c|}{ Cultivars planted in Fall 1994} \\
\hline Ojebyn & Unknown & $2.6 \mathrm{c}-\mathrm{e}$ & $2.3 \mathrm{e}-\mathrm{h}$ & $2.5 e-g$ \\
\hline Ben Lomond & (Consort $\times$ M agnus) $\times$ (Brodtorp $\times$ Janslunda) & $1.3 a-c$ & $1.7 \mathrm{c}-\mathrm{f}$ & $1.5 a-c$ \\
\hline Ben Alder & Ben $M$ ore $x$ Ben Lomond & $2.1 \mathrm{a}-\mathrm{e}$ & $1.9 \mathrm{~d}-\mathrm{f}$ & $2.0 \mathrm{c}-\mathrm{e}$ \\
\hline Ben N evis & (Consort $\times \mathrm{M}$ agnus) $\mathrm{x}$ (Brodtorp $\mathrm{x}$ Janslunda) & $2.3 \mathrm{~b}-\mathrm{e}$ & $1.9 \mathrm{~d}-\mathrm{f}$ & $2.1 \mathrm{c}-\mathrm{f}$ \\
\hline Ben Connan & Ben Sarek x Ben Lomond & $1.2 \mathrm{ab}$ & $1.1 \mathrm{ab}$ & $1.2 \mathrm{ab}$ \\
\hline Storklas & SunderbynII x (Consort x Kajaanin M.) & $2.0 \mathrm{a}-\mathrm{e}$ & $1.6 \mathrm{~b}-\mathrm{e}$ & $1.8 \mathrm{~b}-\mathrm{e}$ \\
\hline $4 \mathrm{D} / 10$ & Ben $\mathrm{N}$ evis $\mathrm{x} O$ jebyn & $1.6 \mathrm{a}-\mathrm{d}$ & $1.4 \mathrm{a}-\mathrm{d}$ & $1.5 \mathrm{a}-\mathrm{c}$ \\
\hline $11 D / 2$ & Bieloruskaja Sladkaya x Titania & $1.0 \mathrm{a}$ & $1.0 \mathrm{a}$ & $1.0 \mathrm{a}$ \\
\hline $26 \mathrm{C} / 5$ & Titania $\times$ Ben $\mathrm{N}$ evis & $1.2 a b$ & $1.2 \mathrm{a}-\mathrm{c}$ & $1.2 \mathrm{ab}$ \\
\hline Ben Alder $x / 5$ & Ben Alder $x$ op & $3.1 \mathrm{e}$ & $3.0 \mathrm{~g}-\mathrm{j}$ & $3.1 \mathrm{~g}$ \\
\hline O jebyn & Unknown & $2.9 \mathrm{de}$ & $3.1 \mathrm{hij}$ & $3.0 \mathrm{~g}$ \\
\hline Titania & Altajskaja D. x (Consort x Kajaanin M.) & $1.0 \mathrm{a}$ & $1.0 \mathrm{a}$ & $1.0 \mathrm{a}$ \\
\hline Ben Lomond & (Consort $\times$ M agnus) $\times$ (Brodtorp $\times$ J anslunda) & $1.7 \mathrm{a}-\mathrm{e}$ & $1.7 \mathrm{c}-\mathrm{f}$ & $1.7 \mathrm{~b}-\mathrm{d}$ \\
\hline $80 \times 138 / 2$ & Ben Lomond $\times 7 / 72$ & $1.5 \mathrm{a}-\mathrm{d}$ & $3.2 \mathrm{ij}$ & $2.4 \mathrm{~d}-\mathrm{g}$ \\
\hline B.T. x Tit./ 2 & Ben Tirran x Titania & $3.1 \mathrm{e}$ & $3.1 \mathrm{~h}-\mathrm{j}$ & $3.1 \mathrm{~g}$ \\
\hline Tit. $\times$ B.A/ 2 & Titania x Ben Alder & $1.4 \mathrm{a}-\mathrm{c}$ & $2.1 \mathrm{~d}-\mathrm{f}$ & $1.8 \mathrm{~b}-\mathrm{e}$ \\
\hline B.L $x / 7$ & Ben Lomond $x$ op & $2.3 \mathrm{~b}-\mathrm{e}$ & $3.3 \mathrm{j}$ & $2.8 \mathrm{f}-\mathrm{g}$ \\
\hline B.L $\times / 2$ & Ben Lomond $x$ op & $1.3 \mathrm{a}-\mathrm{c}$ & $2.2 \mathrm{e}-\mathrm{g}$ & $1.7 \mathrm{~b}-\mathrm{d}$ \\
\hline $83 \times 80 / 1$ & Beloruskaja Sladkaya x Ben Lomond & $1.0 \mathrm{a}$ & $1.0 \mathrm{a}$ & $1.0 \mathrm{a}$ \\
\hline PC -15 & Ben Lomond $\times 7 / 72$ & $1.5 \mathrm{a}-\mathrm{c}$ & 2.2 ef & $1.9 \mathrm{c}-\mathrm{e}$ \\
\hline PC -17 & Ben Lomond $x 7 / 72$ & $1.7 \mathrm{a}-\mathrm{e}$ & $2.4 \mathrm{f}-\mathrm{i}$ & $2.1 c-f$ \\
\hline
\end{tabular}

${ }^{2}$ Ranking scale 1 to $5 ; 1=$ no symptoms, $5=$ very severe symptoms on leaves. 
Table 2. White pine blister rust (WPBR ) field resistance of black currant genotypes planted at the clone collection in 1997, Experimental Orchard, D abrowice, Poland. M eans followed by the same letter within column do not differ significantly according to D uncan's multiple range test $(P=0.05)$.

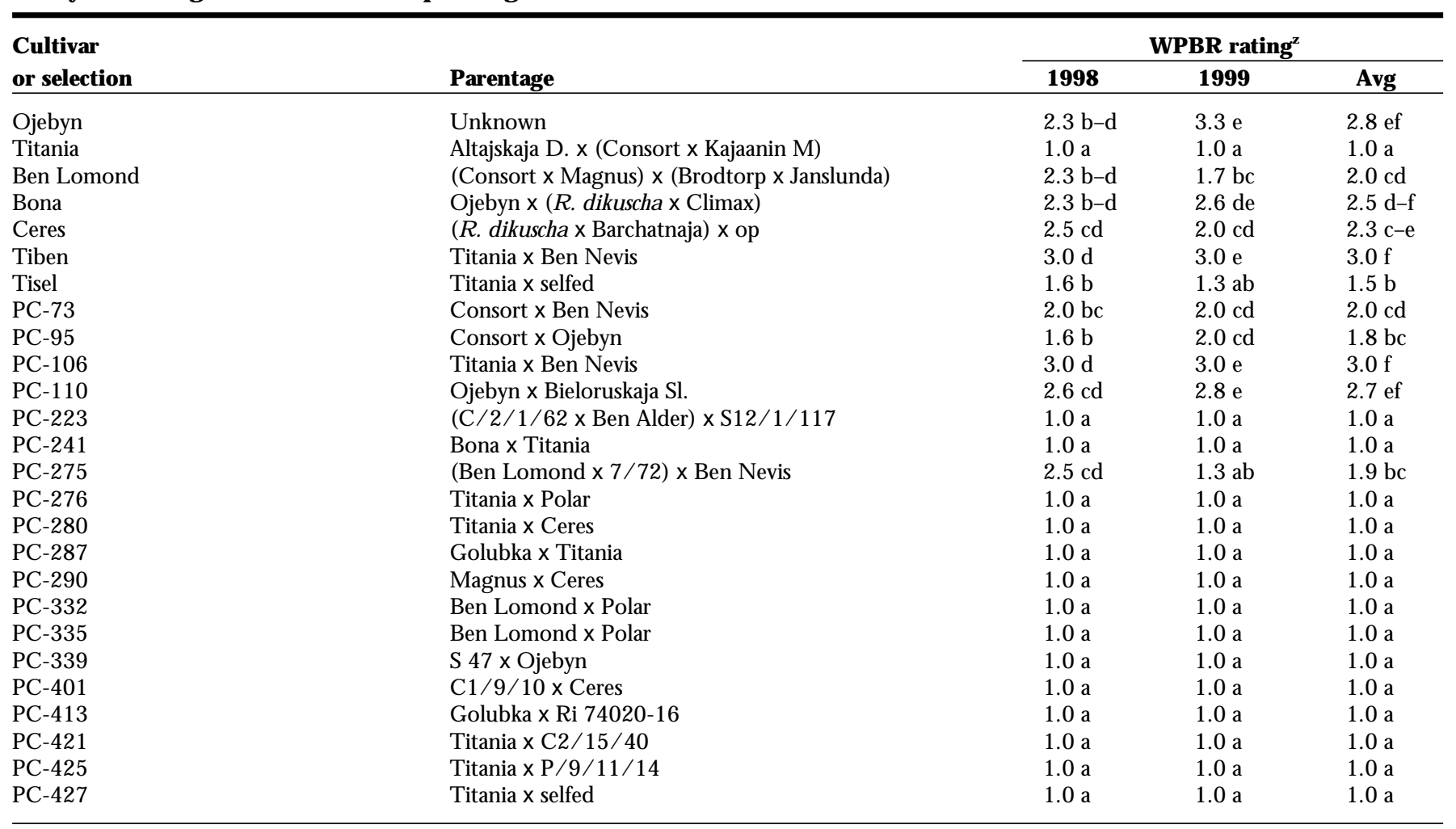

${ }^{\mathrm{z}}$ Ranking scale 1 to $5 ; 1=$ no symptoms, 5 = very severe symptoms on leaves.

and from three plants in the clone collection. O $\mathrm{n}$ each plant five leaves were randomly chosen and examined.

Analysis of variance(AN OVA) was applied to the ranks. D uncan's multiple range test at $5 \%$ level of probability was used for the separation of means.

\section{Weather conditions}

The temperatureand precipitation for themonthsM ay to September 1998 and 1999 are presented (Fig. 1). In central Poland, temperatureswereabove normal during summer in 1999. In 1998 they werevery similar to multiyear average recorded for last 20 years. Precipitation was generally higher than normal during June and July in both years of investigation. These weather conditions were fairly good for fungal disease infection (including WPBR ) in the field.

\section{Results and discussion}

The $F$ values for the ranks of the cultivar evaluation trial were significant in 1998 and 1998 ( $F=4.47, P=0.05$; $F=12.26, P=0.05)$. WPBR infection levels were rather low during the test years and a rank of 3.3 was the highest level of infection observed (Table 1). No uredia were observed on 'T itania' at any time during the study. 'Titania' probably inherited the $\mathrm{Cr}$ gene from 'Consort' (O golcova, 1991) and agrees with earlier research (Pluta et al., 1993). The following selections: 11D/2, $138 \times 76 / 69 \mathrm{~A} / 1,74020-6 \times / 1$, and $83 \times 80 / 1$ showed high field resistance to WPBR (T able 1). In these selections, WPBR resistance genes may have come from cultivars 'BieloruskajaSladkaya' or 'Titania' which were the parents or grandparents.

The $F$ values for the ranks of the selection evaluation trial were also significant in 1998 and 1999 (F =22.14, P $=0.05 ; F=7.02, P=0.05)$. Field evaluation of resistance to WPBR of the breeding selections planted in the collection ispresented (T able2). N o uredia were found in the tested selections marked PC -223, PC -276, PC-280, PC 290, PC-332, PC-335, PC-339, PC401, PC-413, PC -421, PC -425, and PC-427, or on 'T itania', which has the $\mathrm{Cr}$ resistancegene. 'T itania' wasa common parent in the pedigree in most of these selections.

Genotypes with high field resistance to WPBR and other fungal diseases will be included in future black currant crosses. Thebest resistant selections, possessing high productivity, good fruit quality and suitable plant habit, will beincluded in the Polish $\mathrm{N}$ ational Fruit Trials. The best selectionswill benamed and officially registered on the Polish List of Cultivars.

\section{Literature cited}

Broniarek-N iemiec, A., S. Pluta, and A. Bielenin 1997. O cena polowej odpornosci porzeczki czarnej i agrestu na podstawowe choroby grzybowe w hodowlanych kolekcjach roboczych ISK.M at. z O gólnopolskiej Konferencji O chrony R oslin Sadowniczych,:135-136.

Broniarek-N iemiec, A., S. Pluta, and A. Bielenin 1999 Wstepnaocenapolowej odpornosci wybranych odmian i klonów hodowlanych porzeczki czarnej napodstawowe choroby grzybowe. M at. VII Zjazdu H odowców R oslin Sadowniczych, AR Lublin, 4-5. 02. 1999: 449-452.

O golcova, T.P. 1991. Selekcja czernoj smorodinyproszloje, nastojaszczie, buduszczeie. Tipografia "Trud", O riel, Russia 1-381.

Pluta, S. and E. Zurawicz 1993. Black currant (R ibes nigrum L.) breeding program in Poland. Acta H ort. 352:447-453.

Pluta, S., E. Zurawicz, and W. M adry 1993. Phenotypic and breeding values of few black currant cultivars in Central Poland. Acta H ort. 352:455-462.

Pluta, S. and K. H ummer 1996. R ibescollection at the ARS-USDA NCGR in Corvallis, Oregon, USASources of genes used in black currant breeding program in Poland. Problems of fruit plant breeding, collection of scientific articles. Dobele $\mathrm{H}$ ort. Plant Breeding Expt. Sta. L atvian U niv. Agr. 1:77-84, J elgava, Latvia. 